\title{
SHOULD I STAY OR SHOULD I GO? INTERNATIONAL MIGRANTS IN THE RURAL TOWN OF ZITTAUISAXONY AND THEIR POTENTIAL IMPACT ON REGIONAL DEVELOPMENT
}

\author{
Robert Nadler ${ }^{1}$
}

Received 29 April 2011; Accepted 16 December 2011

\begin{abstract}
Given that migration studies mostly focus on rural-urban migration, the explanatory power of theoretic models is questioned for rural immigration. This paper aims at presenting results from a series of qualitative interviews with international migrants in the small rural town of Zittau and its surrounding villages in Eastern Saxony. It is suggested that the study of contrary flows of urban-rural migration needs specific models to better capture the migrants' motivations and situations in a rural context. Rationales to move to rural places as well as the everyday life in the hosting rural community differ strongly from patterns in the urban settings. Thus the central question is how both the migrants as well as the rural communities might benefit from rural immigration.
\end{abstract}

Keywords: Rural immigration; rural community; Saxony; regional development; Lebenswelt

Zusammenfassung: In Anbetracht der ausgeprägten Fokussierung auf Land-Stadt-Wanderung in einem Großteil der Migrationsforschung wird die Erklärungskraft der gängigen Theoriemodelle für die Zuwanderung in ländliche Gebiete hinterfragt. Dieser Beitrag stellt die Ergebnisse einer qualitativen Interviewreihe mit ausländischen Zuwanderern in der ländlichen Stadt Zittau und den umliegenden Dörfern in Ostsachsen vor. Es liegt die Vermutung nahe, dass die Untersuchung entgegengesetzter Ströme von Stadt-Land-Wanderung eigene Modelle braucht, um die Beweggründe zur Migration sowie die aktuelle Situation der Migranten im ländlichen Kontext besser erfassen zu können. Sowohl die Gründe in den ländlichen Raum zu ziehen als auch die konkrete Alltagssituation in der ländlichen Aufnahmengemeinde unterscheiden sich deutlich von den Mustern in großstädtischen Umgebungen. Somit stellt sich vornehmlich die Frage wie sowohl die Migranten als auch die ländlichen Gemeinden von internationaler Immigration in ländliche Gebiete profitieren können.

Schlüsselwörter: ländlichen Einwanderung, ländlichen Gemeinde, Sachsen, die regionale Entwicklung, Lebenswelt

\footnotetext{
1 Robert Nadler, Leibniz-Institut für Länderkunde, Schongauerstraße 9, 04328 Leipzig, Germany; e-mail: R_Nadler@ifl-leipzig.de
} 


\section{Introduction}

Most studies dealing with globalisation focus on urban centres as nodes in inter- and transnational networks of change and innovation (e.g. Sassen, 2002; Lange, 2007). This also holds true for migration studies, in which the theoretical frameworks are strongly built on the premise of urban environments (Jentsch \& Simard, 2009; Haug, 2000; Lebhart, 2002; Favell, 2008). Here, rural regions are mostly conceptualised as areas of origin for migration flows. According to a wide-spread understanding, this is due to the fact that in rural and peripheral regions problems are concentrated (ageing, emigration for economic reasons, thinning out of infrastructural assets) and opportunities are fewer than in bigger cities. This position stresses the dominance of push-factors in rural regions, which encourage migrants to leave.

In this sense, the rural region of Eastern Saxony represents a typical case for a region with dominant push-factors. It still suffers from post-socialist economic restructuring. The large socialist agriculture cooperatives have vanished. Single state-owned industrial facilities have been fractionised (Karlsch \& Schäfer, 2006). The regionally important energy sector (coal mining) became more efficient in terms of labour intensity. So, there was a rapid decline in available jobs throughout the whole economy. This led to a massive emigration during the 1990 s and the early 2000s. Still today unemployment is relatively high, and the economic base of the region has not yet recovered from the post-socialist restructuring.

In addition, it struggles with the growing pressures of global competition. The general rural pattern of ageing and depopulation is here even stronger than in other rural regions in the EU. Furthermore, after 40 years of relative isolation in the GDR state, the region is composed of a rather homogeneous population, which is not very experienced with international immigration and foreign cultures (SMS 2009). Thus, the region is not typically attractive for international immigrants.

On the other hand, the accession of the New Member States to European Union in 2004 and the subsequent opening of Saxon borders towards the Czech Republic and Poland produced a previously unknown mobility potential for people in the border triangle. Eastern Saxon stakeholders hope for Czech and Polish immigrants to compensate for the shortages in skilled labour within the region.

Some of the few foreigners who have already immigrated there were approached during the field work of the FP7 project DERREG ${ }^{2}$, which dealt with the impacts of globalisation on rural regions in the EU. These migrants were interviewed about their rationale to move there and about their current everyday life situations in the region. The interviews revealed some interesting aspects concerning the (missing) welcoming atmosphere in the region and the (potential) impact of migrants on regional development.

The paper will begin with a brief overview of the current situation in the case study area of rural Eastern Saxony and the rural town of Zittau in which the empirical field work was situated. In the third section some methodological remarks should inform the reader about the sampling and interview design as well as the analysis approach. The fourth section presents the empirical findings and their discussion. Finally, results are concluded in the sixth section.

\section{Rural Eastern Saxony}

\subsection{Context situation in the case study area Eastern Saxony}

In Saxony, the Direktionsbezirk is an administrative level (NUTS II) between the level of the Bundesland and the communal level (counties and municipalities). The Direktionsbezirk Dresden is located in the Eastern part of Saxony, bordering the Czech Republic and Poland, and consists of the counties Bautzen, Görlitz, Meißen and Sächsische Schweiz-Osterzgebirge. Furthermore the City of Dresden - the Saxon Capital - is part of the Direktionsbezirk. Apart from the Saxon Capital of Dresden, with its 513,200 inhabitants (in 2009, see table 1), these

\footnotetext{
${ }^{2}$ For more information: www.derreg.eu
} 
counties are characterised by small and medium-sized rural towns, agricultural and brown coal mining land use, and low population density.

\begin{tabular}{|c|c|c|c|c|c|c|c|}
\hline & & $\begin{array}{l}\text { Population } \\
\text { in } 1,000\end{array}$ & $\begin{array}{l}\text { Share of } \\
\text { population } \\
65+\text { in \% }\end{array}$ & $\begin{array}{l}\text { GDP per } \\
\text { capita in } €\end{array}$ & $\begin{array}{l}\text { Available } \\
\text { net income } \\
\text { per capita } \\
\text { in } € \\
\end{array}$ & $\begin{array}{l}\text { Value added } \\
\text { in } \\
\text { agriculture, } \\
\text { forestry \& } \\
\text { fishery in } \\
\text { million } € \\
\end{array}$ & $\begin{array}{l}\text { Labour } \\
\text { force in } \\
\text { agriculture, } \\
\text { forestry \& } \\
\text { fishery in } \\
1,000 \\
\end{array}$ \\
\hline & & \begin{tabular}{|l|}
2009 \\
(since 1999)
\end{tabular} & $\begin{array}{l}2009 \\
(\text { since 1999) }\end{array}$ & $\mid \begin{array}{l}2009 \\
(\text { since 1999) }\end{array}$ & $\begin{array}{l}2009 \\
(\text { since 1999) }\end{array}$ & $\begin{array}{l}2009 \\
\text { (since 1999) }\end{array}$ & $\begin{array}{l}2009 \\
\text { (since 1999) }\end{array}$ \\
\hline \multirow[t]{2}{*}{ Germany } & total & $81,874.8$ & $20.7 \%$ & 29,278 & 18,983 & \begin{tabular}{|l|l|}
17,310 \\
\end{tabular} & 0 859.0 \\
\hline & change & $-0.3 \%$ & $27.5 \%$ & $19.4 \%$ & $21.2 \%$ & $-22.1 \%$ & $-9.2 \%$ \\
\hline \multirow[t]{2}{*}{ Saxony } & total & $4,178.3$ & $24.7 \%$ & 22,212 & 15,881 & 726 & 40.9 \\
\hline & change & $-6.6 \%$ & $37.0 \%$ & $31.7 \%$ & $21.1 \%$ & $-24.2 \%$ & $-24.8 \%$ \\
\hline \multirow[t]{2}{*}{$\begin{array}{l}\text { City of } \\
\text { Dresden } \\
\end{array}$} & total & 513.2 & $22.2 \%$ & 29,271 & 16,135 & 18 & 1.4 \\
\hline & change & $7.5 \%$ & $29.0 \%$ & $25.6 \%$ & $15.3 \%$ & $-7.5 \%$ & $-22.1 \%$ \\
\hline \multirow[t]{2}{*}{\begin{tabular}{|l} 
Case \\
study area
\end{tabular}} & total & $1,120.3$ & $25.4 \%$ & 19,398 & 15,847 & 281 & 15.1 \\
\hline & change & $-10.6 \%$ & $45.3 \%$ & $32.3 \%$ & $23.8 \%$ & $-24.2 \%$ & $-26.8 \%$ \\
\hline
\end{tabular}

Tab 1. Socio-economic statistics Direktionsbezirk Dresden. Source: Destatis, AK VGR; Statistical Office of Saxony; own calculations, 2011.

The post-socialist transition affected the case study area with a massive de-industrialisation throughout the 1990s. In addition, the regionally important brown coal mining sector was made more efficient, and the large-scale agricultural cooperatives were privatised and split into smaller organisational units. Thus the region witnessed a rapid loss of jobs and people started to emigrate to more prosperous regions mostly in Western Germany or to the large cities in Eastern Germany (e.g. Dresden, Leipzig, Berlin).

The current economic situation is characterised by both stabilisation and decline. Table 1 indicates that the demographic development of the region is problematic. The Saxon population decline is faster than the national one. Leaving out the City of Dresden, the case study area is positioned even worse. Furthermore, the population is aging rapidly in the case study area. Though in 2009, still having a slightly smaller percentage of elder people (older than 65 years) than Saxony, the growth of this share is more dynamic in the rural counties of the case study area.

The GDP per capita has to be interpreted as an indicator of convergence of the economic power to the German average level. The growth in the decade 1999-2009 is more dynamic than in Germany, but nominal values of the GDP per capita are still below Germany's national level. However, due to the above average performance of the City of Dresden, the Direktionsbezirk has a GDP per capita which is above Saxon average. When it comes to the available net income per capita, the pattern is similar. The income level in 2009 was still below the German equivalent, but the growth rates since 1999 are slightly higher than in the national average. Here, especially the rural counties could profit from this development much better than the City of Dresden.

As an example for the decline of agriculture, forestry and fishery as traditional economic activity in the rural counties, the change rate of the number of the active labour force is listed for the period 1999-2009. It is obvious that the labour force declined nearly three times as rapid as in the German average, and stronger than in the rest of Saxony. Also the value added in these sectors decreased more rapidly than in the rest of Germany.

It could be concluded that the case study area of Eastern Saxony is a region which is marked by an ongoing process of economic catch-up to the German national level. Furthermore, after a period of economic down-turn in the early 1990s and a massive emigration towards more 
prosperous regions in Germany, Eastern Saxony today struggles with above average shrinking and aging of its population. In addition, the first sector activities (agriculture, forestry and fishery) are declining more rapidly than in other regions in Saxony and in Germany, indicating an ongoing restructuring of the rural economic base. For the people who did not opt for emigration, patience is necessary (Beetz 2009): still the regional labour market is characterised by above average unemployment rates. Currently, regional stakeholders as well as scientists pay more and more attention to the emerging problem of a skilled labour shortage in the rural counties, which hinders economic prosperity (cf. Arent \& Nagl 2010). On first glimpse this labour shortage seems to contradict the factual high rates of long-term unemployment. Yet, it is an indicator of a mismatch between the skills offered by the unemployed and the skills needed by regional companies (Rowthorn 2009).

\subsection{Eastern Saxony as a destination for international migrants?}

The indicators presented suggest that the case study area is quite the opposite of a prosperous centre attracting international flows of inward migration. This assumption could be affirmed when looking at the statistics about the resident foreign population in the last ten years (see table 2).

\begin{tabular}{|l|r|r|r|r|r|}
\hline & $\begin{array}{l}\text { Case study } \\
\text { area }\end{array}$ & Dresden & Görlitz & Zittau & Hoyerswerda \\
\hline Total population in 2010 & $1,103,812$ & 523,058 & 55,596 & 28,212 & 37,379 \\
\hline Foreign population 2010 & 21,323 & 24,692 & 2,160 & 634 & 658 \\
\hline Foreign population share 2010 & $1.9 \%$ & $4.7 \%$ & $3.9 \%$ & $2.2 \%$ & $1.8 \%$ \\
\hline Total population in 2000 & $1,234,755$ & 477,807 & 61,599 & 32,775 & 50,203 \\
\hline Foreign population 2000 & 22,107 & 17,513 & 1,285 & 1,114 & 619 \\
\hline Foreign population share 2000 & $1.8 \%$ & $3.7 \%$ & $2.1 \%$ & $3.4 \%$ & $1.2 \%$ \\
\hline $\begin{array}{l}\text { Foreign population share change } \\
\text { 2000-2010 }\end{array}$ & $7.9 \%$ & $28.8 \%$ & $86.2 \%$ & $-33.9 \%$ & $42.8 \%$ \\
\hline
\end{tabular}

Tab 2. Development of foreign population in the Direktionsbezirk Dresden 2000-2010; source: Statistical Office of Saxony; own calculations, 2011.

Obviously, the share of foreigners in the case study area is well below the German average of 8.8 per cent $^{3}$ during the last ten years. Whereas the City of Dresden as the major regional urban agglomeration hosts 4.7 per cent, the case study area Eastern Saxony only has a share of 1.9 per cent in foreign population (both in 2010). The share of foreigners increased between 2000 and 2010 by 7.9 per cent. This is caused by the fact that the German population shrinks more rapidly than the foreign population. However, local developments vary from town to town. The rural town Görlitz (approx. 56,000 inhabitants) - located directly at the Polish-German border and having its twin part Zgorzelec on the Polish side - could evidence a period of rapid increase of foreign residents in the last ten years. This specificity is driven by Polish citizens who profit from the higher quality and lower prices of housing in the German part of the twin city Görlitz/Zgorzelec. Looking at the rural town of Hoyerswerda (approx. 37,000 inhabitants), we see a slight growth of the foreign population, which is contrary to the massive shrinking of the German population. This leads to a rapid growth of 42.8 per cent in the share of foreigners. The town of Zittau contrasts this picture with a massive decline in foreign population in total, and as percentage number, even though the town is located right in the German-Polish-Czech border triangle.

Generally, the case study area is not a typical destination of international migration flows and it represents a typical case for a region with dominant push-factors. Obviously, the economic difficulties and the demographic challenges in the region deter international migrants to move to

\footnotetext{
${ }^{3}$ Federal Statistical Office Germany, 2011: https://www-genesis.destatis.de/genesis/online/ (Accessed 22 November 2011)
} 
rural Eastern Saxony. Nonetheless, there is a small population of migrants who reside in the case study area.

\section{Methodology}

\subsection{Sampling and interviewing}

Sampling international migrants in Eastern Saxony is difficult as the share of resident foreign population is very small. In addition, due to data protection, public authorities will not provide information about relevant work migrants. Thus, it was necessary to focus on a smaller spatial context to be able to understand local social networks and access foreigners through these contacts. The border town of Zittau (approx. 28,000 inhabitants) was chosen for the sampling. Zittau is a typical small rural town in Eastern Saxony, which suffered from post-socialist unemployment and out-migration. Yet, a contradictory aspect made it more interesting for this study than other rural towns in the case study area: on the one hand it is located in the border triangle with the Czech Republic and Poland, and it functions as an urban centre for the rural villages surrounding the town, the chances to access international immigrants should theoretically be higher than in other rural towns in the case study area. On the other hand, Zittau witnessed a shrinking of its foreign population by almost 50 per cent in the last 10 years. Thus, the question is: What is going on in Zittau that foreigners avoid it even though it has a rather advantageous location towards the EU's New Member States?

\section{Sample of migrants}

The sampling plan (cf. Kelle \& Kluge, 1999) included the following diversity criteria: country of origin; gender; education level; current occupation; age; marital status; duration of stay in the host region. The sampling strategy was based on a first phase of desk research, in which the largest employers in Zittau were investigated. These were mainly the local hospital, some machinery firms and two different Universities of Applied Sciences. These institutions were asked if they employ foreigners, and if they would help with organising interviews. In a second phase potential interview partners were looked for on the site, by asking shop owners or employees of ethnic businesses for an interview. Third, interview partners mediated contacts to further migrants within their local social networks.

For being eligible, migrants had to be self-employed, employed or looking for a job at the moment of the interview, and they had to have come to Zittau or the surrounding villages from a foreign country. In sum, we have interviewed 15 migrants in Zittau and the surrounding villages. The sample includes various biographic backgrounds and motivational patterns, e.g. GDR contract workers, former asylum seekers, family-related chain migrants, as well as highskilled professionals. Most of the migrants have their origins or have spent some life time in large urban agglomerations before moving to the rural town Zittau.

7 out of 15 interviewees were women. The age of the migrants ranged from 23 to 61 years, with most of the interviewees being between 30 and 50 years old. Although only 7 interviewees have children, 12 interviewees are already married. Furthermore it could be mentioned that 5 of them are married to a German partner. Eight out of the 15 migrants are highly-skilled, having achieved at least a university degree or in some cases even doctoral degrees. The migrants are mostly working in positions with managerial work content (e.g. managing directors of restaurant, professors, real estate agents, medical doctors, etc.).

Three migrants could be considered as non-skilled migrants, having only attended minimum levels of schooling in their countries of origin and not having participated in further professional training. Four migrants are low-skilled, having attended some form of professional training. These non- and low-skilled migrants are either working in secondary service positions (such as waiters in diners or housemaids) or they are unemployed. One migrant is unemployed due to health reasons. She is participating in a professional requalification according to her physical abilities. In another case the unemployment is a long-term pattern of the migrant's biography, with a political asylum seeker's history. 
Only two out of the 15 migrants are currently self-employed: one running two restaurants and the other as a real estate agent. The high-skilled migrant workers are employed mostly on unlimited contracts, whereas the less skilled migrants are employed on temporary or limited schemes. One of the migrant workers decided to attend a German university curriculum in order to retrain for a different profession.

Most of the migrants in Zittau are characterised by a stable economic situation with income levels that help them to be self-supporting in the region without using social security schemes provided by the federal or the local authorities. 6 out of 15 migrant workers occupy professional positions with above average income, compared to the regional level. Only three cases are dependent on unemployment benefits and social security payments.

\section{Interview design}

Data collection followed a qualitative approach, using interviews that were a mixture of biographic narratives and problem-centred interviewing. A set of questions was used to guide the interviews' narrations which included the following topics: the migrant's knowledge of the country and region prior to arrival; the motivation to come to the region; the current working situation in the region; the professional experience before and after arrival; the general living situation; the family background and social networks; the first experience upon arrival in the region; future plans; satisfaction with the overall situation in the region; and suggestions for improvements regarding the situation of other migrants in the region. In average, the interviews had a length of one to two hours. The interviews were recorded and transcribed.

\subsection{Analysis of the interviews}

In order to analyse the interviews, a typology of international migrants was developed. According to Kluge (2000), typification is generally done by using categories according to which to analyse the single cases and to group them into clusters with internal homogeneity and external heterogeneity. Traditional typification in migration studies mainly uses the motivations for migration as well as the moments of arrival as categories for typification (cf. Currle \& Lederer, 2004; Geis, 2005). However, these approaches are oriented to historic aspects of the migrants' lives. The author's assumption is: Once migrants have stayed long-term in their host region, once they start to become integrated into the societal and institutional structures of the host region, the current everyday life becomes more dominant in the migrants' mind than their migration history. Consequently, migration motives might not offer the best insights into the current lifeworlds (Lebenswelten) of the migrants in the host region.

For the analysis of the 15 interviews, the concept of Lebenswelt as an alternative category for typification was used. The concept of Lebenswelt, or the English equivalent 'lifeworld', dates back to early phenomenologists, such as Husserl, and refers to the experience of the everyday socio-spatial horizon (Buttimer, 1976). According to Kraus $(2000,2004)$ and his constructivist interpretation of the phenomenological term, a person's Lebenswelt consists of the subjective perception of one's own life circumstances (Lebenslage). Lebenslage refers to the material and immaterial personal circumstances such as e.g. the work situation, the access to and power over material resources, the housing, the social network as well as the own physical abilities and health (Kraus 2004, p.9). Complementary, Lebenswelt is the individual recognition of these circumstances by the respective person. Thus, Lebenswelt is the individually constructed reality of the everyday life (Kraus, 2004, p.9).

This means we should ask for the migrants' perception and experience of his- or herself in a given socio-spatial context. The central issue is, what sense a migrant gives to his or her presence in the host region. Only using this approach, it is also possible to identify potential impacts of migrants for regional development as it provides insights about the migrant's openness and optimism towards the host region and the fact of 'being there' as well as the migrant's perception of the openness of the host community towards him- or herself. Hence, the interviewees were typified according to their individual everyday lifeworld orientations (lebensweltiche Orientierung). 


\section{Empirical findings: Impacts of international work migrants on rural development in Eastern Saxony}

Due to the relatively small sample typification was limited to two types, which should have contrasting lifeworld orientations. Basically, I have identified a first type of work migrants which could be named the 'professionally oriented' and a second type of work migrants termed 'private life oriented'. In the following section, these two types will be presented (section 4.1.). Then it will be discussed what impact they might have on the regional development of Zittau and rural Eastern Saxony (section 4.2.). The two migrant types will be characterised using the following central sub-categories of their lifeworld: a) general lifeworld orientation; b) the relationship to rural Eastern Saxony; c) the relationship to the rural people; and d) their integration into the rural community. Citations from the interviews will be presented in order to illustrate the character of the identified types.

\subsection{Types of migrants in rural Eastern Saxony}

\section{The 'professionally oriented' migrant}

General lifeworld orientation: This type of migrant is primarily focused on the job-related aspects of his or her lifeworld. An ambitious career planning goes together with a subordination of private life-related issues to the professional necessities. Often professionally oriented migrants live in single households and have no children, even when already being a middle-aged person. In case the professionally oriented migrants have a family or stable partnerships, they expect of their related parties a full understanding of their individual professional future plans. The following quote of one interviewee might illustrate this fact:

'My wife is a medical doctor; she could find a job everywhere. But me, I have to find a professorship. It has to be a university. We have already talked about it. If the moment arrives, if it would really be the case, I would prefer to stay in Saxony, if it would be possible. But it if would not be possible ... it is a nomadic society, a globalised world ... we have talked about it. [My wife] commented that she, if it would be necessary, could even imagine moving to a different European country, or perhaps Canada or the USA, wherever I would have a job offer'. (Interviewee No. 2)

Relationship to rural Eastern Saxony: The relationship to the rural area is rather ambivalent. On the one hand, the high educational level leads to a positive evaluation of life in a rural context. In particular, the proximity to nature, the opportunity to live a more ecological and healthy lifestyle as well as the tranquillity are appreciated. On the other hand, rurality is also negatively evaluated, in terms of provinciality. Here, living and working in the Eastern Saxon rural periphery is sometimes even described as a complete new and contrasting experience, which represents a break with well-known urban life styles:

'Zittau as zero-point experience: this means, everything what you have learnt so far you have to give up more and more, you have to distance yourself from the structures of the developed understanding. Then you could experience this absolute zero-point experience. Only then you could learn and develop totally new structures, and only then you can feel at ease here'. (Interviewee No. 3)

The professionally oriented migrant is aware of the fact that there is a lack of certain infrastructures, amenities and services in the rural area. For example, 'appropriate' urban housing is scarce; the cultural offer is limited; and the shopping infrastructure does not fulfil the migrant's expectations. As the professionally oriented migrant is often employed in highly specialised jobs (e.g. scientific research, medical professions, IT sector, or management), he/she has a pronounced demand for the latest business relevant knowledge. These knowledge updates frequently take place in international conferences, in international professional networks and platforms. Thus, this migrant type sustains a latent relationship to distant urban agglomerations (e.g. periodic trips to large cities), which represent knowledge hubs. These 
relations to urban agglomerations could also lead to multilocal forms of life between the rural area and professionally relevant large cities, within two households.

Relationship to the rural people: The professionally oriented type of migrant limits his/her social relations in the rural area mostly to colleagues in the same employing organisation or other professional peers. The relationship to rural people is considered as a distanced position in the personal mind map:

'I feel - how do you say - acquiesced by the most people. You know, with the time, when you hold your head up, and even when it comes to a conversation and you could argue well, when you enter into a dialogue with a certain comprehension and knowledge, then it is mostly that the local people retract. Then they are not anymore active, applying this sentiment 'You don't belong here'. But then they become acquiescing. A distant way of remaining in silence. That's the character of the mass of the local population'. (Interviewee No. 3)

However, professionally oriented migrants also do not have a strong interest in becoming involved. Often they are informed about current debates and topics of the rural public, but they evaluate the public discourse culture as being rather provincial and often unintelligible. According to migrants of this type, the native people in rural Eastern Saxony are rather narrowminded, closed and afraid of foreign and new things. This opposes exactly this type of migrants' self-understanding as being cosmopolitan, open-minded to and interested in the unknown. Thus, interest in the native population is limited.

Integration into the rural community: Integration into the rural community is not a primary objective of the professionally oriented work migrants. Rather it might become a means to an end, if it supports their professional career. Professionally oriented migrants spend most of their time at work or dealing with professional issues. Thus, leisure time within the rural community is limited, and interaction with persons outside the work environment is seldom. Given this rather superficial relationship to the rural community and the orientation to global peer groups and networks of acquaintances in distant urban agglomerations, this migrant type does not problematise being less integrated into the rural community. Consequently, the latent discrimination and xenophobia in rural Eastern Saxony, which is perceived by these migrants, is considered a structural problem of the region but not as an issue related to the person themselves. Due to his/her high education level, this work migrant does not feel addressed by dismissive mind states of the rural Saxons. These migrants understand discrimination and xenophobia as originating from socio-economically disadvantaged groups and targeting other deprived minorities.

\section{The 'private life oriented' migrant}

General life world orientation: The life world orientation of this type of migrant is characterised by a central position of private life-related issues (e.g. family, partnership, friends, leisure activities, volunteering and participation in associations). In contrast to the professionally oriented migrant, this type's job and professional issues are subordinated to the private life. The job is considered a means to an end, in order to earn the living, to improve the material basis of the household, or even to finance leisure activities. This is not to say that the professional sphere is unimportant. Quite the contrary, it plays an important role in order to sustain the private life. Also, the professional sphere often played a more dominant role in former biographic periods of this migrant type. However, as time moves in attention is shifted to the private life, as the following quote might illustrate:

'I am geared to my children. I'm still regretting that I have not done any vocational training, nothing substantial. And now I'm only fighting for that my children do not have to experience the same I have lived through, and that they might have a better future. For myself, honestly, I do not have any plans anymore'. (Interviewee No. 9)

Relationship to rural Eastern Saxony: The central position of the private life goes along with a more intimate relationship to rural Eastern Saxony than is the case for the professionally 
oriented migrant. Based on a profound social integration within family ties and circles of friends, migrants of this type perceive Eastern Saxony as being a new home. The private life oriented work migrant defines 'home' to be the place where the persons are who relate most closely to him or her. This is then in Eastern Saxony, and not elsewhere. Even if migrants of this type grew up or had lived in urban agglomerations and initially were rather sceptical about life in a rural periphery, their evaluations change during the time of residency in this habitat. This is often caused through an intensification of local social relations and networks.

'How could I say something different from my husband? I cannot go somewhere without my family. But I guess, moving with my husband to another city, we don't know anyone there who could help him. You would have to start from the scratch'. (Interviewee No. 11)

Relationship to the rural people: The relationship to the native rural population is rather ambivalent. Depending on the length of stay in Eastern Saxony, and on the degree of cultural proximity or distance of the country of origin, migrants of this type develop different relational patterns to the broader public. The longer they are in the region, and the closer their original culture is to the Saxon one, the more they show affinities to build relations to other persons in the region outside of their families and closer circle of friends. Often this is accompanied by serious efforts (e.g. by developing a position of mutual understanding, by taking the other's perspectives) to establish a good relationship to the regional population:

'The economic situation, the unemployment. On the one hand I also understand that if you have worries your mood is not so good. Here, you can see the smile of the people a bit more seldom. More with sorrow and a bad mood. [...] I say to myself, I have a job, I earn quite well. So, I do not have to present myself as if I can afford certain things. We pay attention to this. I had my first Western car much later, once I had realised, my neighbour is unemployed, at home. Then I will not show off, that I have a decent income and a good life. As a foreigner sometimes you have to be a bit considerate'. (Interviewee No. 6)

In case the migrant's roots are located in a culturally distant country (e.g. non-Christian, developing countries, etc.), establishing contacts with and mutual understanding for the native people is more difficult. Private life oriented migrants from these countries narrow their social networks to people with similar cultural roots and integration problems, or to those natives who are trusted by the migrants. This often leads to a certain isolation within their own family or ethnic group (e.g. Turkish and Kurdish migrants). Such situations might reinforce the migrants to make plans to leave Eastern Saxony again:

'Honestly, I did not have any serious problems because we know a lot of people. It is now nearly 14 years or more, we have good contacts. But people who don't know you, when you go outside, they stare at you. For example my mother, she wears the head scarf. And she really never goes out. Only when she has to go to the doctor. But she is always affronted, and stared at. And when she comes back home she starts crying and is in a bad mood. She never goes outside, she is only at home'. (Interviewee No. 9)

Integration into the rural community: Equivalent to the relationship to the rural people, the integration into the community follows a bi-polar pattern. Although private life oriented migrants make efforts to integrate and accept the necessity to adapt to a regional social climate, single migrants are more successful than others. Being in a mono-national family hinders integration, in particular when having a strongly varying cultural background or being a woman. On the other hand, being in a bi-national or even German-immigrant mixed family facilitates integration into the rural community. Male migrants of this private life oriented type tend to be better integrated than females. Furthermore, having an individual interest in the broader public, or in regional political issues, helps one to become involved.

Nonetheless, within the group of private life oriented migrants, the presence of migration motives such as asylum seekers, Spätaussiedler, or GDR contract workers was more dominant 
than for professionally oriented migrants. Thus, private life oriented migrants seem to be more affected by prejudices and stigmatisation.

Given that these migrants make efforts to become integrated, this latent opposition by the rural community leads to frustration among these migrants. This distinguishes private life oriented migrants from the professionally oriented ones, who care little about the issue of being integrated into the rural community. Private life oriented migrants sometimes even feel uncomfortable in this situation and think about leaving Eastern Saxony for more ethnically mixed regions in Western Germany or Berlin.

\subsection{Discussion: Migrants' possible impacts on rural development in Eastern Saxony}

Scientific studies, so far, have pointed to different impacts international immigrants could have on the development of rural areas. Born (2007), for example, argues that immigrants represent new social actors within a rural region, who could be mobilised for participation in regional development issues. Furthermore, they are consumers of personal services as well as public infrastructures. Thus, they help to maintain a certain level of service provision - both in the public and private sector. In 2003, the international research project Rural-In (see: http://www.ngo.at/rural-in/) surveyed international immigrants in rural areas in Spain, Austria and Portugal. The results highlight the importance of the cultural enrichment and the labour potential that comes along with immigrants. Yet, generally there is still a lack of sytematic research about international immigrants into rural areas (Jentsch \& Simard 2009) while there is much literature about the impact of international migration on regional development in the home region (e.g. through remittances, return migration) (cf. de Haas 2010). Only second home ownership and the related rural gentrification is an established field of rural immigration research (e.g. Phillips 2005). Given this need to analyse the impact of other immigrant groups than (rather wealthy) second home owners, the study of migrants who are active in rural labour markets could add to an understanding of migration-induced rural development processes.

The two presented types of migrants in Eastern Saxony show a different degree of integration into the rural area of Eastern Saxony. In terms of the socio-economic background, the professionally oriented migrants have more advantageous resources to become integrated. However, they tend to have a smaller affinity towards integration in the rural community. On the other hand, private life oriented migrants tend to prioritise the establishment of stable roots in their new 'home'. This goes along with struggles to sustain the own families' life in this rather economically weak case study area. But how do the rationales of the individual migrants and the region of Eastern Saxony go together? What possible impact might these international work migrants have on regional development? Table 3 summarises the main perspectives that might arise from the two migrant types' presence in rural Eastern Saxony.

\begin{tabular}{|c|c|c|}
\hline & $\begin{array}{l}\text {,Professionally oriented } \\
\text { migrant }^{\text {, }}\end{array}$ & ,Private life oriented migrant" \\
\hline Opportunity for the migrant & $\begin{array}{l}\text { Enhance professional career } \\
\text { - Eventually: presence in rural } \\
\text { area as competitive } \\
\text { advantage }\end{array}$ & $\begin{array}{ll}\text { - } & \text { Improvement of personal } \\
\text { living conditions } \\
\text { - } & \text { New home for family }\end{array}$ \\
\hline $\begin{array}{l}\text { Possible impact on regional } \\
\text { development }\end{array}$ & $\begin{array}{ll}\text { - } & \text { Multiplier / Mediator } \\
\text { - } & \text { Knowledge import } \\
\text { - } & \text { Global links } \\
\text { - } & \text { High-skilled Professional / } \\
& \text { Rural intelligentsia }\end{array}$ & $\begin{array}{ll}- & \text { Cultural diversity I } \\
& \text { Heterogeneisation } \\
- & \text { Social engagement } \\
- & \text { Attenuation of demographic } \\
& \text { problems }\end{array}$ \\
\hline Stay or go? & Go & Stay (go) \\
\hline Challenges for regional policy & How to retain and root? & $\begin{array}{c}\text { How to integrate into the regional } \\
\text { labour market/economy? }\end{array}$ \\
\hline
\end{tabular}

Tab 3. Possible impact of migrant types on regional development in rural Eastern Saxony. 


\section{Opportunity for the migrant}

The professionally oriented migrant profits from having migrated to rural Eastern Saxony in terms of promoting their own career and working in a challenging position. Being in rural Saxony equals the realisation of a professional opportunity. The professionally oriented migrant has often signed a work contract before migration or had been asked to immigrate by a regional employer. Depending on the actual profession, being settled in rural Saxony might in itself become a competitive advantage on the labour market (e.g. professional planners or spatial scientists dealing with shrinkage or demographic problems). Professionally oriented migrants are mostly high-skilled and their presence in rural Saxony could even raise their competencies.

The private life oriented migrants often relate being in rural Saxony to an improvement of the general living conditions. Their motives of migration are more heterogeneous than those of professionally oriented migrants. However, all these different motives merge into one central aspect: the opportunity of re-installing their own life in rural Eastern Saxony, far from the problems in the region of origin. Eastern Saxony has become their new home. This is often reinforced by having rooted their families in the region. The long-term presence is accompanied by growing circles of friends and intensifying contacts with the rural Saxons. Also the participation in local, native associations rises with the length of time in the region (e.g. local football club, allotment garden association). In sum, for these private life oriented migrants, migration to rural Saxony offers the establishment of a new home and new roots. With varying success, they also seek to become part of the regional social community. Here, these migrants stated that the small rural community in and around the town of Zittau provides a manageable population size, which would probably not be the case in a large urban agglomeration where contacts are supposed to be more anonymous.

\section{Possible impact on regional development}

As professionally oriented migrants are high-skilled and work in specialised labour market segments, they are strongly integrated into global networks of information. Hence, these migrants act as mediators or multipliers of information from rural Eastern Saxony into global networks and vice versa. On the one hand, they import new, professional knowledge into the region. On the other hand, they facilitate the distribution of knowledge and information from rural Eastern Saxony to the world through their mobility. This exported knowledge and information could be both professional and region-specific. This provides the opportunity for the region to develop positive images and attractiveness on a global scale (e.g. images/stories about the region as transported by professionally oriented migrants) while continuously having an inflow of the latest expert knowledge from global networks. The latter might then become relevant for the productivity of regional companies. The combination of their different cultural backgrounds, high education levels and professional skills as well as their cosmopolitan attitudes and circular migration biographies make these migrants important stakeholders for the rejuvenation of the rural intelligentsia in Eastern Saxony.

The private life oriented migrants also import professional skills to rural Saxony. Yet, more important is their cultural impact on the rather homogeneous Saxon rural communities. During four decades of relative isolation in the GDR, the rural population became immobile and inexperienced with foreign and international immigrants. Private life oriented migrants report that they interpret the native Saxons' xenophobia as an overstretched fear of the unknown. Thus, the long-term presence of these private life oriented migrants gives native rural Saxons the opportunity to engage with foreign cultures and to become more experienced with and open-minded to the unknown. The development of intercultural competencies among native Saxons could subsequently facilitate cross-border exchange with Poland and the Czech Republic, which today is still less developed than in other EU border regions. In addition, private life oriented migrants have a strong tendency to engage in local associations and development initiatives. Thus, they are important stakeholders for the survival of the societal life (e.g. civil society, vivid community) in a depopulating rural Saxony. A final aspect also refers to their affinity to raise families in rural Saxony. This is a direct benefit for the region in terms of demographic development. 


\section{Stay or go? Migrants' future perspectives and related challenges for regional policy}

The positive impact of both types of migrants, presented above, has first of all a potential character. In reality, these impacts are no self-fulfilling prophecies. International migration to rural Eastern Saxony even causes problems, both for the migrants and the region. It is not a straight 'win-win' situation. The author will thus focus on the possible issues for regional policies, which might enhance the realisation of opportunities.

Professionally oriented migrants in rural Saxony were characterised as job-focussed highpotentials, who represent important human capital for the regional labour market. Yet, these migrants have a clear affinity to remain mobile and to leave the region again for other professional challenges. Sometimes, this labour aspect is combined also with the process of 'rurality becoming a push-factor', and migrants seeking for emigration to urban agglomerations. Concerning professionally oriented migrants, a central question is therefore, how can these migrants be retained in rural Saxony? How is it possible to root these migrants in rural Saxony? Knowing that particularly social relations have a binding function, policies should orientate to social integration into the broader, not job-related, community. However, given the ongoing flexibility of labour markets, and individual mobility becoming a social imperative, one could also ask, if migrants' retention is a feasible strategy? Perhaps regional politicians have to accept the continuous circulation of these professionally oriented migrants? Then it would be essential to place their own region as a hub within international migration flows in order to profit in some way from the temporary presence and the transnational bridging function of these migrants.

By contrast, private life oriented migrants have a strong will to stay in rural Saxony. They are bound by family ties and they are integrated into the rural Saxon communities. So, this type of migrant is not as mobile and ephemeral as the professionally oriented one. The problem here rather refers to the fact that rural Eastern Saxony is an economically struggling region (see section 2). Thus, private life oriented migrants are often working in jobs that do not reflect their professional education (brain waste). This is due to problems with the recognition of foreign educational degrees. Other private life oriented migrants are unemployed as there are no jobs for them in the region. Thus, rural Eastern Saxony do not profit from these migrants' human capital. In addition, the provision of social security causes new costs. Here, the central question is, how can these migrants be integrated into a regional labour market? How can these migrants secure their economic independence and add efficiently to the regional economic productivity? Some of the private life oriented migrants in rural Saxony also reported thinking about leaving the region, if the individual economic problems exceed a certain threshold. Thus, it is an urgent task for regional policy to facilitate economic success in order to retain these migrants. Possible measures for labour market integration could include programmes to recognise foreign education degrees, professional retraining in cooperation with regional companies, or supporting business start-ups of migrants. A helpful improvement could also be to issue work permits more rapidly to asylum seekers and Spätaussiedler (ethnically German resettlers from Eastern Europe).

Another finding of the interview series in rural Saxony is the fact that nearly all migrants of both types have come to the region for a variety of motives other than the region itself. This is an important fact given that EU regions are faced with increasing competition for human capital. A region which is not attractive itself might struggle with growing disadvantages. Large urban agglomerations attract international migrants through their internationally spread images. In Germany, cities have known labels: Frankfurt/Main as a centre of the finance industry, Hamburg as an international trade centre with its port, Berlin as a creative city and political centre, etc. International immigrants go there with a clear expectation of what living in these places will be like. Our international migrants mainly had no idea what the rural town of Zittau and rural Eastern Saxony would be like. The sparse ex ante knowledge about the region was interfused with prejudice about Eastern Germany and with fuzzy images about life in Germany in general. Rural Saxony does not display a clear and known image which might facilitate attraction of international migrants. Developing a specific regional profile and image could facilitate to attract international migrants in a less random way, perhaps making migrants come for the region itself. 


\subsection{Relevance of results for migration theories}

The empirical results of this study in rural Eastern Saxony reveal major shortcomings of traditional and alternative migration theories for the study of rural immigration. In fact, 'ethnic communities' (cf. Fawcett, 1989; Rainer \& Siedler, 2008) approaches do not work in rural Saxony because the critical mass of immigrants is missing. Theoretical approaches based on 'transnational social spaces' (Bürkner, 2005; Pries 2001, 2007) seem inadequate because rural regions become more peripheralised and less accessible in relation to urban agglomerations (by cut-backs in public expenditure on public transport, poor ICT connectivity, longer geographic distances to major transport hubs like high-speed train stations and airports, public discourse etc.). For similar reasons, the approaches stressing global labour markets for high-skilled expatriates (Sassen, 2002; Florida, 2004) only have small explicative power. There are only a few large multinational enterprises in rural Saxony. And these few branches of multinational companies have no headquarters function. Thus, the only high-skilled employment is provided by branch SMEs, public universities and hospitals.

A theoretical framework designed for rural immigration has to take rural particularities into account. First attempts have been made (Fuguitt \& Beale, 1996). Recent debates conceptualise rural immigration as being driven by counter-cultural/anti-consumerist lifestyles (Schmied, 2005), by rural gentrification (Gallent \& Tewdwr-Jones, 2000), by rural tourism (Paniagua, 2002), by ecological and green movements (Jones et al., 2003), or by counter-urbanisation (Jentsch, 2007). However, in rural Saxony none of these explanatory models helps to understand rural immigration. One has to admit that immigration to rural Saxony happened partially for labour market conditions. The professionally oriented migrants arrived for jobs. But they are neither part of a global expatriate community nor are they working as seasonal agricultural or tourism workers. They arrived due to the presence of high-skilled jobs in public institutions and specific niche sectors such as the local hospital or the local universities. On the other hand many of the private life oriented migrants have not chosen the region on their own, but have been located there through governmental programmes (e.g. distribution of asylum seekers and Spätaussiedler under federal law, or GDR contract workers).

Thus, in the case of rural Saxony, an appropriate migration theory would have to integrate the political sphere more specifically. As mentioned before, migrants did not come for the rural region itself. Future research, targeting the development of a specific rural migration model has to consider the role of political stakeholders and different regulatory scales such as the national immigration law and its distributing function.

This also points to the fact, that there are certain specific labour market niches in rural areas (Jentsch, 2007). There are certain niches in rural Saxony that will have a growing demand in labour force, e.g. health care and personal services. In studying rural immigration, labour remains an important element, but it should be conceptualised as regionally specific labour market niches instead of global expatriate labour markets, as is the case for urban agglomerations.

In addition, it was found that some of the migrants in rural Saxony did not migrate in the narrow definition of a single, long-term relocation of residency. Rather, these migrants used varying forms of maintaining connections with larger urban centres in proximity. For example, one migrant's family lived in Dresden (about 523,000 inhabitants; 120 kms distance). Two Czech migrants had their friends and family in Liberec in the Czech Republic (about 102,000 inhabitants; $30 \mathrm{kms}$ distance). Thus, connections to larger cities in geographic proximity seem to play an important role. The migrants develop new multilocal forms of spatialisation, living their everyday lives in urban and rural places at the same time. Migration theory dealing with rural immigration has to take this fact into account. First attempts have been made by Dienel (2009), who tried to conceptualise the relation between urban centres and rural peripheries as complimentary spaces that are used by migrants or multilocal people in an alternating way and for complimentary functions. This idea might also help rural regions to redefine their own functional position and image, which might attract further immigrants. 


\section{Conclusion}

The study of 15 international work migrants who moved to the rural town of Zittau or its surrounding villages in Eastern Saxony revealed that there are two types in terms of the current life world orientation: The first type is composed of professionally oriented migrants, who focus on their work environment. They often have a circular migration history, are very mobile and have cosmopolitan attitudes. In addition, they tend to leave the region again for future career advancement. Yet, as they are globally connected and highly skilled, they represent important human capital for rural Saxony. The central question is thus, how can regional policies help anchor and retain these migrants? A first point might be to improve their integration into the broader community outside their professional peer group. Involving these migrants in local communities and the civil society could raise their interest in rural Saxony and their willingness to stay. In addition, one should also think about these migrants as being continuously mobile, following circular migration patterns. Probably, retention is not the appropriate strategy, but becoming a hub in certain migration circuits is a more realistic option for regional policy.

The second type of migrant orientates to the private life aspects. Migrants of this type are more willing to become involved with native Saxons; they engage in associations and development initiatives. Thus, the social connection to the region is well established. However, the central problem for these migrants is integration into the labour market. Often they work in jobs not equalling their professional education or they are unemployed. The main task for regional policy is to integrate these migrants into the labour market. Possible measures could include programmes to acknowledge foreign educational degrees, to match migrants' skills with regional labour needs by retraining, or to foster self-employment. Given the growing social security costs as well as the increasing skilled labour shortage in rural Eastern Saxony, this will become a major issue in the near future.

In addition, both types of migrants have not come to rural Eastern Saxony for the region itself. This suggests that the region is lacking a distinct and defined image to attract high-skilled migrants. Given the sharpening competition for skilled labour in the European Union, the region should develop a clear image as a tool for the attraction of migrants. Otherwise the inflow of migrants will remain random and less manageable.

Against the initial observation that the rural town of Zittau is characterised by the contradiction of being located in the German-Polish-Czech border triangle but having lost half of its foreign residents in the last ten years, the interviewed migrants all reported high levels of general satisfaction in the region. Those migrants intending to stay felt largely at ease with the local community. Thus, the presented sample and this paper could not answer the question of what might have caused the shape decrease in the foreign population.

Finally, migration theories were identified as being focussed on urban agglomerations, conceptualising rural regions as sources of outward migration. Rural immigration is not present in these concepts. The author suggests a further broadening of the empirical data base on rural immigration in order to derive a specific migration model for rural regions. The presented study reveals possible directions for this task. On the one hand, rural regions might stabilise old, and establish new labour market niches (e.g. renewable energies, sustainable tourism, natural resources, health care) which lead to own labour induced migration in-flow. On the other hand, the rural regions might develop new place-specific images and take the role of complimentary spaces to the urban agglomerations. Probably people will develop multilocal lives between the city and the countryside which have a more complex character than the traditional second home ownership in terms of combining the two places in the everyday life.

\section{Acknowledgements}

The author would like to thank the DERREG project team at Leibniz Institute for Regional Geography in Leipzig, namely Prof. Dr. Joachim Burdack, Michael Kriszan and Tobias Krol, who have helped during field work and the analysis of the interviews. 
[1] Arent, S. \& Nagl, W. (2010). Ostdeutscher Fachkräftemangel bis 2030. In: Ifo Dresden berichtet, No. 6/2010, pp. 40-43.

[2] Beetz, S. (2009). Analysen zum Entscheidungsprozess Jugendlicher zwischen 'Gehen und Bleiben': Die Relevanz kollektiver Orientierungen bei Migrationsentscheidungen ostdeutscher Jugendlicher. In Schubarth, W. \& Speck, K., eds., Regionale Abwanderung Jugendlicher: Theoretische Analysen, empirische Befunde und politische Gegenstrategien (pp. 135-152). Weinheim, München: Juventa.

[3] Born, K. - M. (2007). Zuwanderung in den peripheren ländlichen Raum. Eine Chance? In: Schmied, D. \& Henkel, G. (eds.): Leerstand von Gebäuden in Dörfern - Beginn der Dorfauflösung oder Chancen durch Umnutzung? RURAL, Vol. 1, pp. 19-36. Göttingen: Cuvillier.

[4] Bürkner, H. - J. (2005). Transnationale Migration. Zeitschrift für Wirtschaftsgeographie, 49(2), 113-122.

[5] Buttimer, A. (1976). Grasping the Dynamism of Lifeworld. Annals of the Association of American Geographers, 66(2), 277-292. Doi: 10.1111/j.1467-8306.1976.tb01090.x.

[6] Currle, E. \& Lederer, H. W. (2004). Migration in Europa: Daten und Hintergründe. Stuttgart: Lucius \& Lucius.

[7] Dienel, H. - L. (2009). Multilokales Wohnen zwischen Kontrasträumen: Befunde und Konzepte zu individuellen und politischen Raumpartnerschaften. In Informationen zur Raumentwicklung, No. 1/2.2009, pp. 117-123.

[8] Favell, A. (2008). Eurostars and Eurocities: Free Movement and Mobility in an integrating Europe. Oxford: Blackwell.

[9] Fawcett, J. T. (1989). Networks, linkages, and migration systems. International Migration Review, 23(3), 671-680.

[10] Florida, R. (2004). The Rise of the Creative Class: And how it's transforming work, leisure, community and everyday life. New York: Basic Books.

[11] Fuguitt, G. V. \& Beale, C. L. (1996). Recent Trends in Nonmetropolitan Migration: Toward a New Turnaround? Growth and Change, 27(2), 156-174. Doi: 10.1111/j.14682257.1996.tb00901.x.

[12] Gallent, N. \& Tewdwr-Jones, M. (2000). Rural second homes in Europe: Examining housing supply and planning control. Aldershot: Ashgate.

[13] Geis, M. (2005). Migration in Deutschland: interregionale Migrationsmotivatoren. Wiesbaden: DUV.

[14] de Haas, H. (2010). Migration and Development: A Theoretical Perspective. International Migration Review, 44(1), 227-264. Doi: 10.1111/j.1747-7379.2009.00804.x.

[15] Haug, S. (2000). Klassische und neuere Theorien der Migration. Arbeitspapiere No. 30. Mannheim: Mannheimer Zentrum für Europäische Sozialforschung.

[16] Jentsch, B. (2007). Migrant integration in Rural and Urban Areas of New Settlement Countries: Thematic Introduction. International Journal on Multicultural Societies, 9(1), 112.

[17] Jentsch, B. \& Simard, M. (2009). Introduction: Key Issues in Contemporary Rural Immigration. In Jentsch, B. \& Simard, M. (eds.): International Migration and Rural Areas: Cross-National Comparative Perspectives (pp. 1-16). Farnham, Burlington: Ashgate.

[18] Jones, R. E., Fly, J. M., Talley, J. \& Cordell, H. K. (2003). Green Migration into Rural America: The New Frontier of Environmentalism? Society \& Natural Resources, 16(3), 221-238. Doi: 10.1080/08941920309159. 
[19] Karlsch, R. \& Schäfer, M. (2006): Wirtschaftsgeschichte Sachsens im Industriezeitalter. Leipzig: Edition Leipzig.

[20] Kelle, U. \& Kluge, S. (1999). Vom Einzelfall zum Typus: Fallvergleich und Fallkontrastierung in der qualitativen Sozialforschung. Qualitative Sozialforschung Bd. 4. Opladen: Leske + Budrich.

[21] Kluge, S. (2000). Empirically Grounded Construction of Types and Typologies in Qualitative Social Research. In Forum Qualitative Sozialforschung 1(1), Article 14. http://www.qualitative-research.net/index.php/fqs/article/view/1124/25000 (Accessed 22 November 2011).

[22] Kraus, B. (2000). „Lebensweltliche Orientierung“ statt „instruktive Interaktion“. Eine Einführung in den Radikalen Konstruktivismus in seiner Bedeutung für die Soziale Arbeit und Pädagogik. Reihe Forschung \& Lernen. Berlin: Verlag für Wissenschaft und Bildung.

[23] Kraus, B. (2004): Lebenswelt und Lebensweltorientierung - eine begriffliche Revision als Angebot an eine systemisch-konstruktivistische Sozialarbeitswissenschaft. http://www.sozialarbeit.ch/dokumente/lebensweltorientierung.pdf. (Accessed 22 November 2011).

[24] Lange, B. (2007). Die Räume der Kreativszenen: Culturepreneurs und ihre Orte in Berlin. Bielefeld: Transcript.

[25] Lebhart, G. (2002). Internationale Migration: Hypothesen, Perspektiven und Theorien. In: Demographie aktuell, No. 19. Berlin: Humboldt Universität

[26] Massey, D. S., Arango, J., Huga, G., Kouaouci, A., Pellegrino, A. \& Taylor, J. E. (1993). Theories of international migration: A review and appraisal. Population and Development Review, 19(3), 431-466.

[27] Paniagua, A. (2002). Urban-rural migration, tourism entrepreneurs and rural restructuring in Spain. Tourism Geographies, 4(4), 349-371. Doi: 10.1080/14616680210158128.

[28] Phillips, Martin (2005). Differential productions of rural gentrification: illustrations from North and South Norfolk. Geoforum, 36(4), 477-494.

Doi: 10.1016/j.geoforum.2004.08.001.

[29] Pries, L. (2001): Internationale Migration. Bielefeld: Transcript.

[30] Pries, L. (2007). Integration als Raumentwicklung - Soziale Räume als Identifikationsräume. In Deger, P. H. R. (ed.), Der europäische Raum. Die Konstruktion europäischer Grenzen (pp. 123-144). Wiesbaden: VS Verlag.

[31] Rainer, R. \& Siedler, T. (2008). Social networks in determining migration and labour market outcomes: Evidence from the German Reunification. ISER Working Papers, No. 36/2008. Essex: Institute for Social and Economic Research.

[32] Rowthorn, R. (2009). Winners and losers of migration in the European context: economic aspects. In Fassmann, H., Haller, M. \& Lane, D. (eds.), Migration and Mobility in Europe: Trends, Patterns and Control (pp. 15-30). Cheltenham: Edward Elgar.

[33] Sassen, S. (2002, ed.). Global networks, linked cities. New York: Routledge.

[34] Schmied, D. (2005). Incomers and Locals in the European Countryside. In Schmied, D. (ed.), Winning and Losing: The Changing Geography of Europe's Rural Areas (pp. 141166). Aldershot: Ashgate.

[35] SMS/Saxon State Ministry for Social Affairs (2009). Rahmenbedingungen von Migration und Integration im Freistaat Sachsen ab 1990. Working Paper of the OPEN-Project. http://www.soziales.sachsen.de/download/Download_Gesundheit/Migration_Sachsen. pdf (Accessed 22 November 2011). 